\title{
HETEROGENEITY OF HOUSEHOLDS IN THE EURO AREA, HUNGARY, AND POLAND IN TERMS OF THE USAGE OF FINANCIAL ASSETS AND DEBT ON THE BASIS OF THE HOUSEHOLD FINANCE AND CONSUMPTION SURVEY
}

\begin{abstract}
This article analyses areas where there are differences in household behaviour in selected countries in terms of financial assets and debt held. The author hypothesizes that although the Euro Area countries share a common monetary policy - which defines some of the financial market conditions and activity of financial institutions the behaviour of households on financial markets differs considerably. The subject of analysis is the structure of financial instruments held by households and the activity of households on financial markets by age and income. The author also analyses the heterogeneity of households using hierarchical cluster analysis, which shows significant diversity in the percentage of households holding financial assets together with debt as well as diversity in the value of the financial products held by them.
\end{abstract}

Keywords: household finance, financial assets, household debt, distribution of assets. JEL Classification: D14, D31, E21.

\section{Introduction}

In order to assess and compare behaviours and the situation of households in the European Union, a specific survey was conducted. Referred to as

Anna Magdalena Korzeniowska, Maria Curie-Skłodowska University in Lublin, Faculty of Economics, Department of Banking, pl. M. Curie-Skłodowskiej 5, 20-031 Lublin, Poland, e-mail: anna. korzeniowska@umcs.lublin.pl, ORCID: https://orcid.org/0000-0001-9809-5260. 
the Household Finance and Consumption Survey (HFCS), it was run in the form of questionnaire research in all the Euro Area countries (wave 1). Additionally, in the second wave, the Survey was completed with new additions to the Euro Area and two other entries - Hungary and Poland. The first wave data were released in April 2013 (Bover et al. 2016). The second wave was completed in the autumn of 2016 and only partial data are generally available. In this article only the second wave will be analysed, as the period of data collection was shorter and more organised which allowed greater comparability of results. The other reason is the addition of Poland into the survey. The main aim of the article is to compare the usage of financial instruments by households in different countries as well as entanglement of their financial assets and debt. The author hypothesizes that although the Euro Area countries share a common monetary policy, which defines some of the financial market conditions and activity of financial institutions, the behaviour of households on the financial markets differs.

\section{Financial Assets of Households}

As stated in the existing research, there are significant differences in asset behaviours between European countries in relation to each other and to the USA (Arrondel et al. 2016). Research carried out to date implies that the heterogeneity of household behaviours in asset allocation is indicated, among others, by incomes and differences in intergenerational transfers (Arrondel, Roger \& Savignac 2014). It also depends on the economic and institutional environment of households (Arrondel \& Savignac 2016, Christelis, Ehrmann \& Georgarakos 2015). The same can be said of the latest research. The results of the Household Finance and Consumption Survey show that at least $82 \%$ of households in Euro Area countries have financial assets (Table 1), although the share of financial assets in total household assets ranges from $4.6 \%$ in Poland to $24.9 \%$ in the Netherlands, with $17.8 \%$ being the average for the Euro Area. Apart from Poland, the share of financial assets in total household assets is lower by $10 \%$ in Slovenia, Greece, Slovakia, Latvia, and Cyprus, and it is higher by $20 \%$ in Germany, Belgium, and the Netherlands.

Deposits in credit institutions should be considered the most popular financial instrument as they are held by at least $88.1 \%$ of households in Hungary up to $100 \%$ in Finland. The second most popular instruments are voluntary pensions and whole life insurance held by $23.6 \%$ of households on average, but because this position comprises two different instruments, the interpretation of the results requires further thorough and careful study. 


\begin{tabular}{|c|c|c|c|c|c|c|c|c|c|c|}
\hline & 责 & 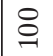 & 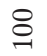 & $\hat{\sim}$ & $\dot{0}$ & $\underset{\vec{N}}{\stackrel{+}{\Delta}}$ & $\vec{Z}$ & $\begin{array}{l}\dot{\partial} \\
\dot{\lambda}\end{array}$ & $\begin{array}{l}\infty \\
\ddot{n}\end{array}$ & \\
\hline & $\frac{u}{n}$ & $\stackrel{\sim}{\infty}$ & $\begin{array}{l}\sim \\
\infty \\
\infty\end{array}$ & $N$ & $\stackrel{m}{0}$ & $\overrightarrow{\mathrm{i}}$ & $\ddot{n}$ & $\begin{array}{l}n \\
n \\
n\end{array}$ & $\stackrel{\bullet}{\leftrightarrow}$ & \\
\hline & $\bar{n}$ & $\begin{array}{l}0 \\
\dot{\sigma}\end{array}$ & $\ddot{n}$ & $\begin{array}{l}\dot{0} \\
\dot{n}\end{array}$ & $\hat{o}$ & $\infty$ & $r$ & \pm & $\grave{o}$ & \\
\hline & 5 & $\begin{array}{l}\text { ?ొ } \\
\text { مू }\end{array}$ & శூర & $n$ & $\hat{b}$ & $\hat{i n}$ & $\ddot{\sigma}$ & 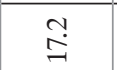 & $\stackrel{n}{\sim}$ & \\
\hline & $\vec{a}$ & $\begin{array}{l}a \\
\infty \\
\infty\end{array}$ & $\begin{array}{l}\infty \\
\text { i }\end{array}$ & $\stackrel{\sim}{\sim}$ & - & $\ddot{n}$ & $n$ & $\frac{m}{i n}$ & $\stackrel{\sim}{i}$ & \\
\hline & 离 & $\begin{array}{l}\infty 0 \\
\stackrel{\alpha}{\alpha}\end{array}$ & ลें & $\stackrel{ }{=}$ & $\nabla$ & $\ddot{i r}$ & $\ddot{\infty}$ & $\stackrel{n}{ \pm}$ & $\stackrel{n}{\sim}$ & \\
\hline & 㐫 & $\stackrel{\sim}{\alpha}$ & $\begin{array}{l}0 \\
\dot{0}\end{array}$ & $\stackrel{m}{\longrightarrow}$ & $\stackrel{\infty}{m}$ & $\infty$ & $\begin{array}{l}0 \\
\infty\end{array}$ & man & $\ddot{F}$ & \\
\hline & $\stackrel{E}{\Sigma}$ & $\stackrel{+}{\leftrightarrow}$ & $\stackrel{y}{a}$ & $\stackrel{\infty}{\sim}$ & $\stackrel{+}{\stackrel{i}{d}}$ & $\stackrel{\forall}{\bullet}$ & $\vec{i}$ & $\stackrel{\sim}{\sim}$ & $\vec{i}$ & \\
\hline & 氠 & $\begin{array}{l}\infty \\
i \\
\infty\end{array}$ & $\vec{\infty}$ & $\stackrel{+}{\sim}$ & $\stackrel{m}{r}$ & $\stackrel{m}{\longrightarrow}$ & $\approx$ & nֶ? & $\ddot{n}$ & \\
\hline & $?$ & $\frac{\overrightarrow{5}}{a}$ & 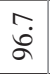 & $\begin{array}{l}0 \\
\stackrel{+}{\sim}\end{array}$ & $\begin{array}{l}\stackrel{\sim}{i} \\
\end{array}$ & $a$ & $\underset{r}{\stackrel{+}{r}}$ & ๗ె & $\stackrel{+}{+}$ & \\
\hline & ב & $\stackrel{\Upsilon}{\infty}$ & $\begin{array}{l}n \\
\infty \\
\infty\end{array}$ & $\overrightarrow{0}$ & $\stackrel{?}{0}$ & $\stackrel{\infty}{0}$ & $\infty$ & $\hat{\infty}_{0}$ & - & \\
\hline & $\bar{u}$ & $\stackrel{\sim}{\infty}$ & $\stackrel{?}{0}$ & $\stackrel{+}{-}$ & $\stackrel{\leftrightarrow}{0}$ & $\stackrel{+}{\stackrel{\sim}{*}}$ & $\underset{\infty}{\infty}$ & $\stackrel{n}{2}$ & - & \\
\hline & છ & $\tilde{\sigma}$ & $\stackrel{\sim}{\sigma}$ & जे & $\stackrel{m}{\longrightarrow}$ & $\vec{m}$ & $\grave{o}$ & $a$ & $\bar{a}$ & \\
\hline & $\underset{|r|}{\alpha}$ & $\begin{array}{l}0 \\
\stackrel{2}{\circ}\end{array}$ & $\begin{array}{l}0 \\
\stackrel{0}{\circ}\end{array}$ & $\begin{array}{l}\dot{\infty} \\
\infty\end{array}$ & $\stackrel{\sim}{\sim}$ & $\stackrel{ }{\exists}$ & $n$ & $\begin{array}{l}n \\
\infty \\
\infty \\
m\end{array}$ & बे & \\
\hline & ص్ & $\begin{array}{l}0 \\
\stackrel{2}{\circ}\end{array}$ & $\begin{array}{l}0 \\
\stackrel{2}{\circ}\end{array}$ & $\dot{i}$ & $\overrightarrow{\mathrm{i}}$ & $\exists$ & $\stackrel{\vartheta}{\exists}$ & $\stackrel{n}{\stackrel{n}{v}}$ & $\stackrel{n}{\sim}$ & \\
\hline & 응 & $\begin{array}{l}0 \\
\stackrel{+}{+}\end{array}$ & 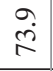 & $\dddot{n}$ & $\stackrel{?}{0}$ & $\stackrel{\infty}{0}$ & $\stackrel{\vec{r}}{\circ}$ & $\stackrel{?}{-}$ & ?! & \\
\hline & 凹 & $\vec{d}$ & ळু & $\stackrel{m}{m}$ & $\stackrel{n}{+}$ & $\vec{m}$ & $\underset{i}{\stackrel{r}{*}}$ & 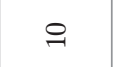 & $\stackrel{n}{\sim}$ & \\
\hline & 떺 & $\begin{array}{l}\infty \\
\infty \\
\infty\end{array}$ & $\begin{array}{l}0 \\
\infty \\
\infty\end{array}$ & $\stackrel{\sim}{n}$ & $\ddot{\sigma}$ & $\stackrel{\vec{r}}{\dot{\sim}}$ & $\underset{\sim}{\stackrel{\Xi}{J}}$ & $\begin{array}{l}\stackrel{\circ}{\sigma} \\
\stackrel{a}{\sigma}\end{array}$ & $\stackrel{\varphi}{\dot{\rho}}$ & \\
\hline & 㿠 & ఫे. & જे & $\vec{m}$ & $\stackrel{\sim}{\forall}$ & $\stackrel{\circ}{\circ}$ & $\stackrel{m}{g}$ & ?ִ & $\stackrel{n}{ \pm}$ & \\
\hline & 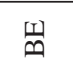 & $\stackrel{a}{\widehat{\sigma}}$ & $\frac{n}{\stackrel{n}{a}}$ & $\vec{\sim}$ & $\stackrel{\infty}{\stackrel{\infty}{\sim}}$ & $=$ & $\hat{b}$ & $\stackrel{+}{\dot{f}}$ & $\ddot{r}$ & \\
\hline & 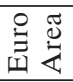 & $\frac{\mathfrak{a}}{a}$ & ڤેळ & $\ddot{\sigma}$ & $\begin{array}{l}\stackrel{\sigma}{\forall}\end{array}$ & $\begin{array}{l}\infty \\
\infty \\
\infty\end{array}$ & $\stackrel{9}{\top}$ & $\stackrel{n}{n}$ & $\stackrel{n}{r}$ & \\
\hline $\overrightarrow{\tilde{\sigma}}$ & 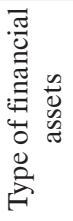 & 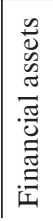 & $\begin{array}{l}\frac{n}{0} \\
0 \\
0 \\
0 \\
0 \\
0\end{array}$ & 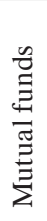 & $\begin{array}{l}\tilde{E} \\
\tilde{0} \\
\infty\end{array}$ & 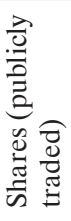 & 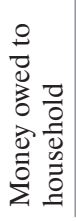 & 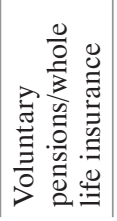 & 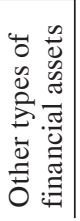 & 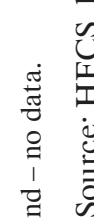 \\
\hline
\end{tabular}




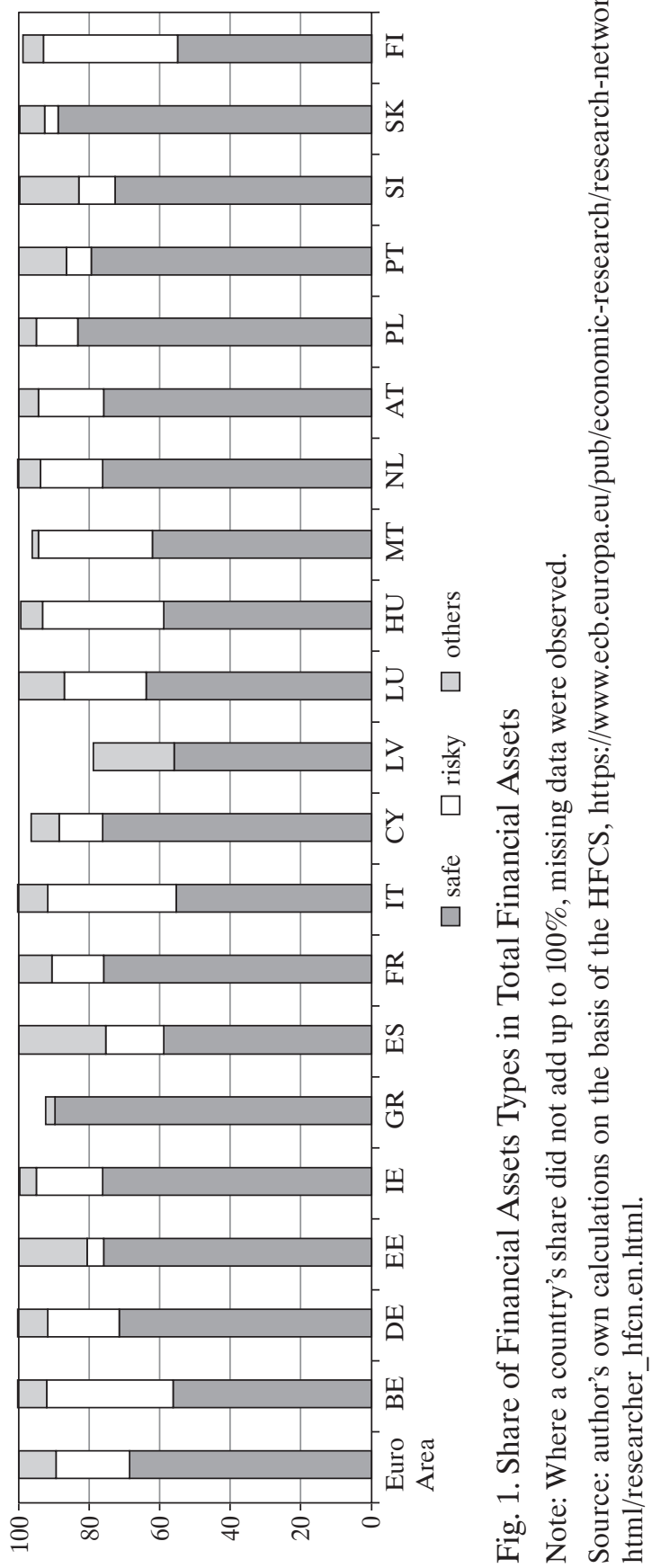


If the share of financial asset types in total financial assets is taken into consideration, the differences between the analysed countries are more pronounced (Figure 1). Safe financial assets consist of deposits and voluntary pension plans with life insurance contracts, while risky assets include mutual funds, bonds, and shares. In total, $68.7 \%$ of household financial assets in the Euro Area is located in safe instruments, $20.8 \%$ in risky ones, and $10.5 \%$ in others. In the twelve out of the twenty researched countries, more than $70 \%$ of the financial assets comprise safe instruments. In Italy, Latvia, and Finland the share of safe assets in total financial assets is the lowest, ranging from $55.3 \%$ to $55.8 \%$.

\section{Households Debt}

In life cycle theory, households tend to stabilise their consumption through the use of credit, topping up their income when the latter is too low - thus allowing consumption to be maintained at its existing level - or by saving and paying off debt in periods when income is higher than that required for satisfactory consumption. But consumers are not always rational in their behaviour (Du Caju et al. 2014). It has been shown at the micro level that there are different factors which influence household debt, such as social interactions (Georgarakos, Haliassos \& Pasini 2014). There is also some limited research linking debt levels with saving (Kukk 2014).

The HFCS analysed several types of debt: mortgage on household main residence (HMR), mortgage on other properties, credit card debt, credit line/overdraft, and other non-mortgage debt. About 85.8\% of household liabilities in the Euro Area is linked to mortgage debt (Figure 2). The highest shares of this type of debt are recorded in Estonia, Ireland, and Portugal.

Within non-mortgage debt, the biggest share is taken up by loans other than credit cards and credit lines/overdrafts.

\section{Use of Financial Assets and Debt - a Country Comparison}

Both financial assets and debt products are provided to households by financial institutions, mostly banks. Very often a household simultaneously has assets in the form of saving or investments and debt in the form of credits or loans. So, the question arises whether households in different countries become involved in the same way in various financial products. To answer that question, some analyses were undertaken. The first was the 


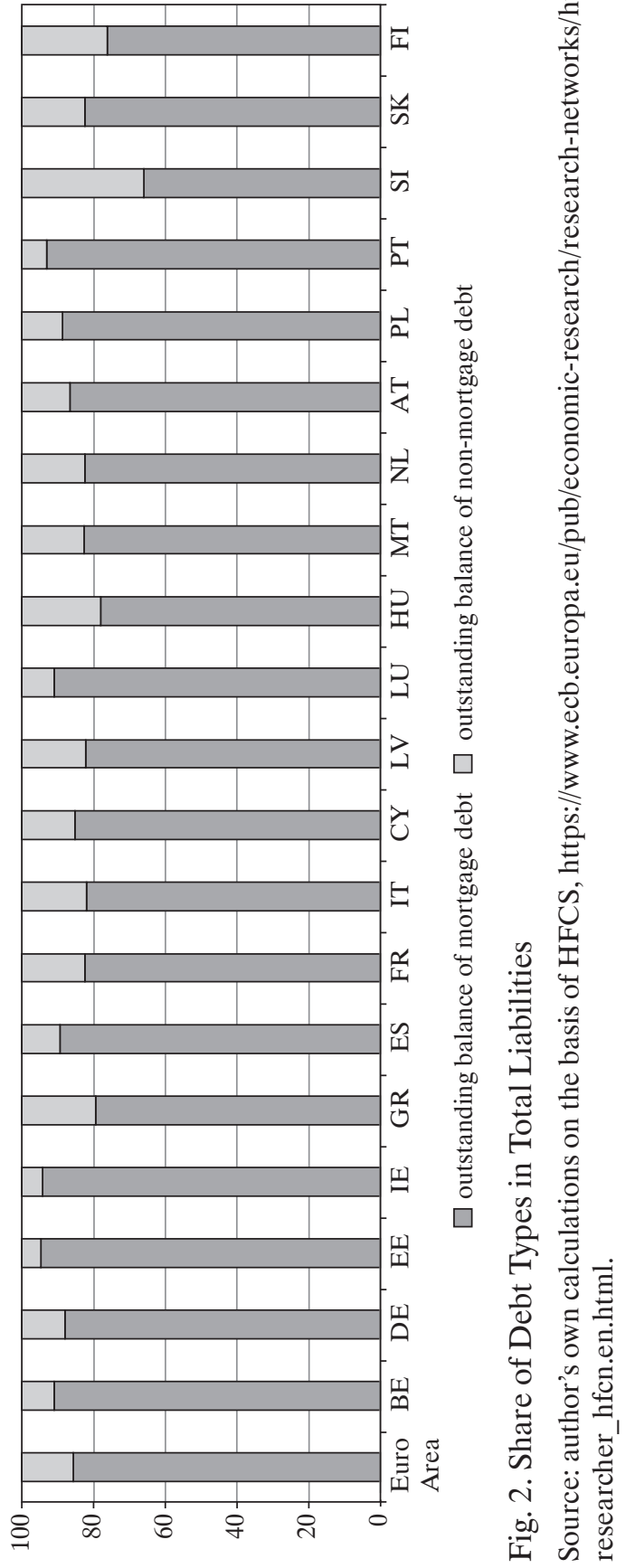


dispersion of the use of financial assets and debt in households, as presented in Figures 3 and 4 (these figures present only selected countries as examples of the general trends).

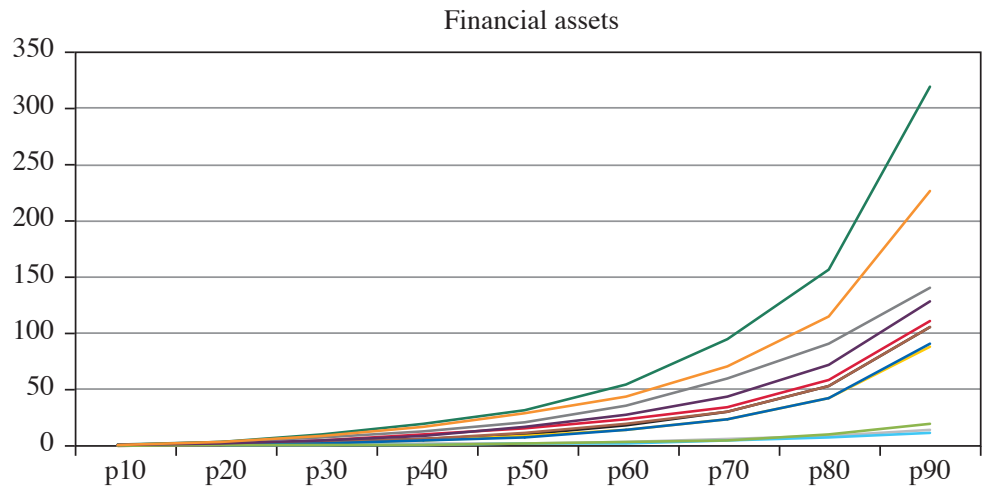

- $\begin{gathered}\text { Euro } \\ \text { Area }\end{gathered}$

Fig. 3. Dispersion of Financial Assets in Households by Income Level

Source: author's own calculations on the basis of the HFCS, https://www.ecb.europa.eu/pub/ economic-research/research-networks/html/researcher_hfcn.en.html.

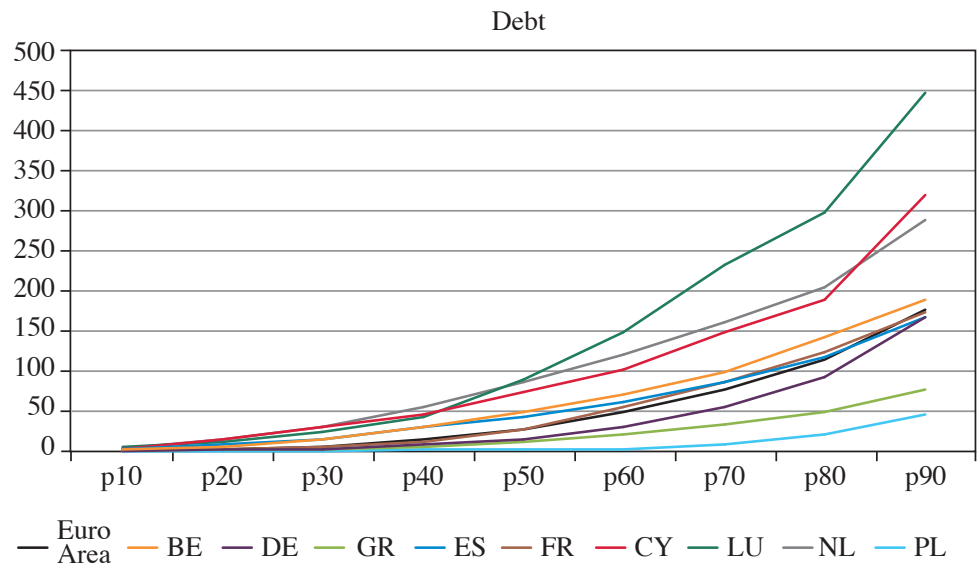

Fig. 4. Dispersion of Debt in Households by Income Level

Source: author's own calculations on the basis of the HFCS, https://www.ecb.europa.eu/pub/ economic-research/research-networks/html/researcher_hfcn.en.html. 
As can be seen, there are noticeable differences between households of varying income level in terms of involvement in financial assets. In some countries, such as Greece, Poland or Slovakia, the rise in asset value follows the change in income very slowly, while in others, such as Luxembourg and Belgium, the value of assets grows exponentially with rising household income. In the case of debt, its growth with income is rather linear. Also, the dispersion of debt between households of different income levels is higher and more distinct.

The second analysis refers both to the share of financial assets in total assets and to the value of debt in accordance with respondents' ages and income levels. It was observed that the highest share of financial assets in total assets in eight out of the twenty analysed countries is enjoyed by respondents from the $75+$ age group. In three countries (Belgium, Spain, and Cyprus), the highest share of financial assets in total assets is enjoyed by people aged 65 to 74 . This is also the case for the youngest respondents in six countries, i.e. Germany, Italy, Austria, Poland, Slovakia, and Slovenia. As for household income, it seems that those households with the highest share of financial assets usually come from the highest earning groups, except in Germany, Ireland, and the Netherlands, where the statement holds true for the group with the smallest income, while in Austria, Cyprus, Belgium, and Malta the other income groups are those most involved.

In contrast to the above, in the case of debt value the most active group in the thirteen countries and in the Euro Area as a whole is people aged 35 to 44. In Belgium, Spain, Malta, and Portugal, even younger groups hold the highest value of debt. And in another three countries, i.e. Germany, Greece, and the Netherlands, the most indebted are 45-54 year-olds. As for income level, only in two countries - Belgium and Cyprus - is most debt accumulated by households in the $80-90 \%$ range. In the remaining countries, the most indebted households are those with the highest incomes.

The third analysis gives a direct comparison of countries in terms of the simultaneous use of financial assets and debt by households. This analysis was carried out by means of both dispersion diagrams and dendrograms, which present the concentration of groups of countries.

The dispersion diagram in Figure 5 illustrates the use of both financial assets and debt by percentage of households involved in these products, whereas the diagram in Figure 8 shows the dispersion of countries by the value of financial products actually held. What is worth noting is the fact that the number of households involved in financial products is relatively high both in terms of assets and debt. This is shown by the concentration 
of countries in the upper part of the diagram in Figure 5. There are a few exceptions, and these are:

a) Italy, with a lower household preference for debt,

b) Greece, with a significantly lower involvement in both types of financial products,

c) Cyprus, with a clearly higher involvement in debt in relation to financial assets than the average,

d) Poland, Slovakia, Hungary, and Latvia, where the relationship between involvement in assets and debt is similar to the average, although the percentage of households involved in both types of products is lower.

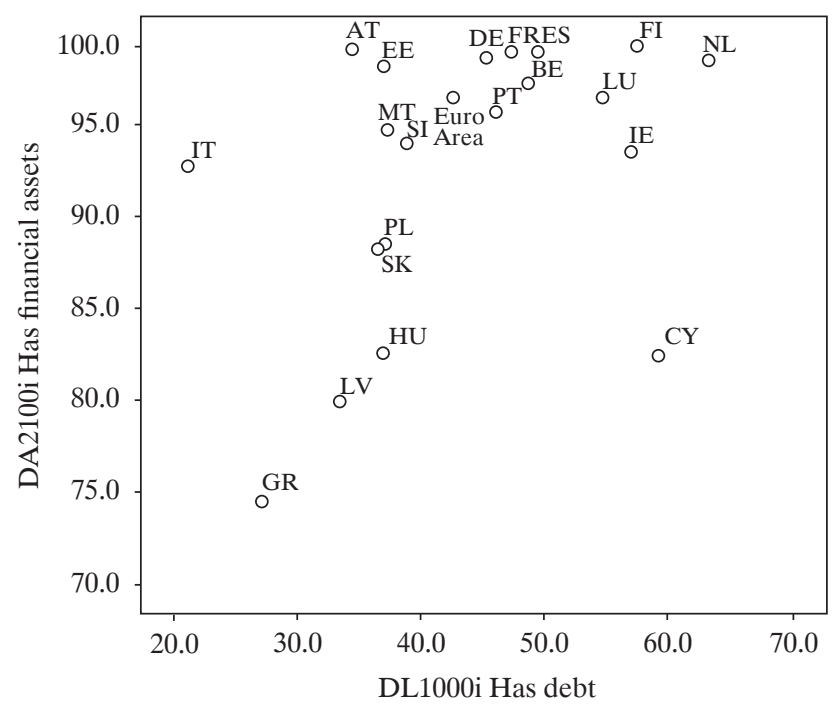

Fig. 5. Dispersion of Countries by Percentage of Households Holding Financial Assets and Debt

Source: author's own calculations on the basis of the HFCS, https://www.ecb.europa.eu/pub/ economic-research/research-networks/html/researcher_hfcn.en.html.

On the other hand, the countries illustrated in Figure 6 are highly concentrated in the lower left-hand corner, which points to similarities in their behaviour in terms of the value of both financial assets and debt. In this case, the exceptions concern:

a) Luxembourg, with households holding very high values of financial assets and debt, while the relation of one to the other maintains a general trend, 
b) Cyprus and the Netherlands as well as Finland, Spain, Portugal, and Ireland, where the value of debt in relation to the value of financial assets is higher than the average,

c) Belgium as well as Malta, Germany, and Austria, where the relationship of asset and debt values is the reverse of that in point b).

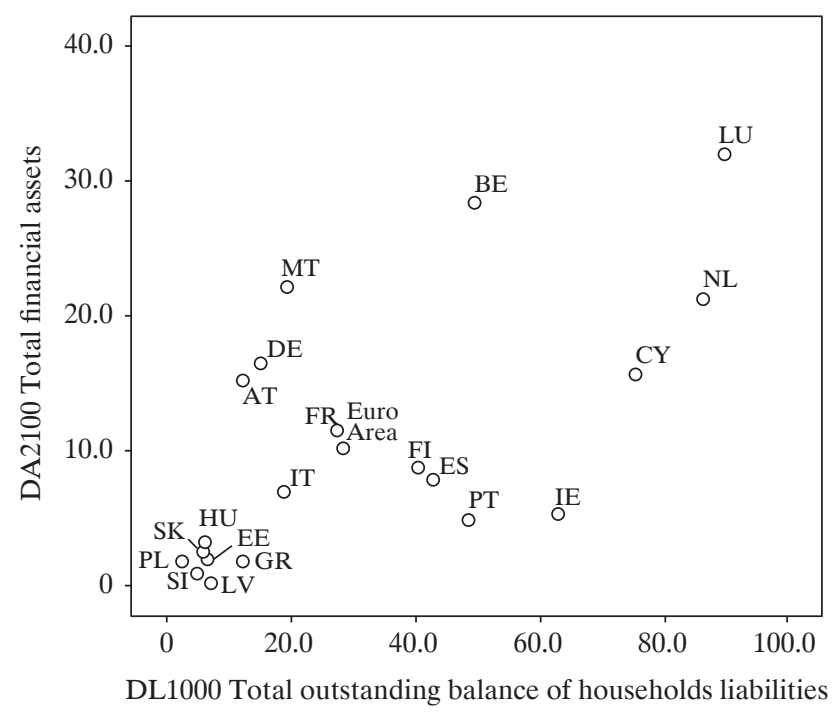

Fig. 6. Dispersion of Countries by Value of Financial Assets and Debt Held by Households

Source: author's own calculations on the basis of the HFCS, https://www.ecb.europa.eu/pub/ economic-research/research-networks/html/researcher_hfcn.en.html.

More accurate research on the heterogeneity of household behaviour in the analysed countries is provided by hierarchical cluster analysis. Dendrograms compiled by the centroid clustering method with square Euclidean distance, with the use of SPSS, are presented in Figures 7 and 8. As in the case of the dispersion diagrams, there are two dendrograms. The first presents the heterogeneity of countries by the percentage of countries holding financial assets and debt, while the second presents the value of both types of products held by households in the countries analysed. 


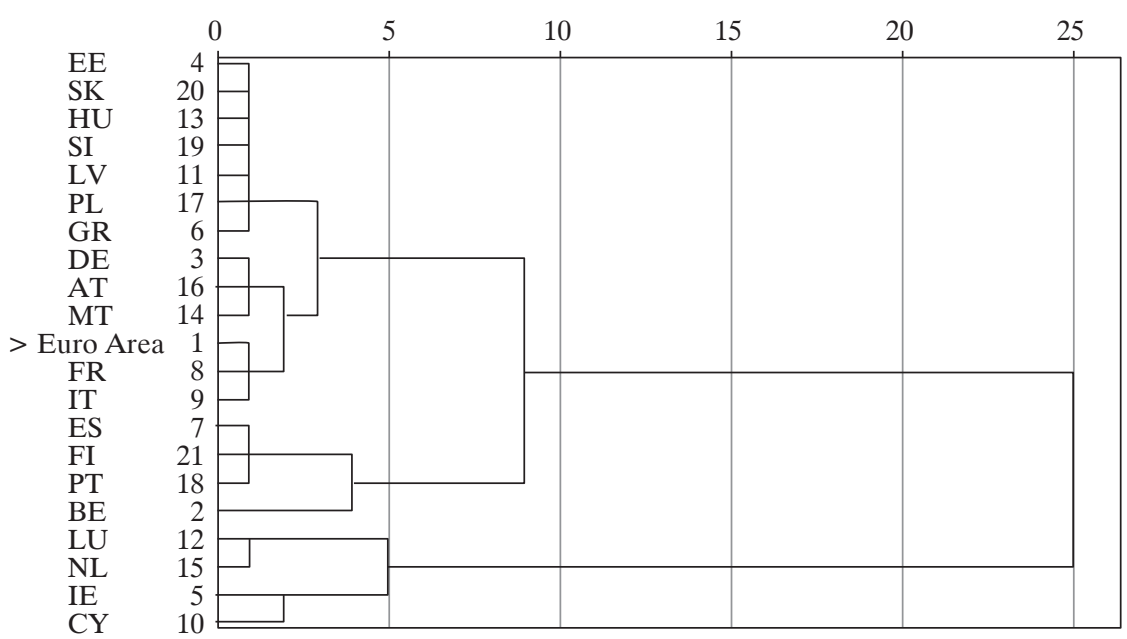

Fig. 7. Clusters by Percentage of Households Holding Financial Assets and Debt (Clusters Combined, Distances Adjusted)

Source: author's own calculations on the basis of the HFCS, https://www.ecb.europa.eu/pub/ economic-research/research-networks/html/researcher_hfcn.en.html.

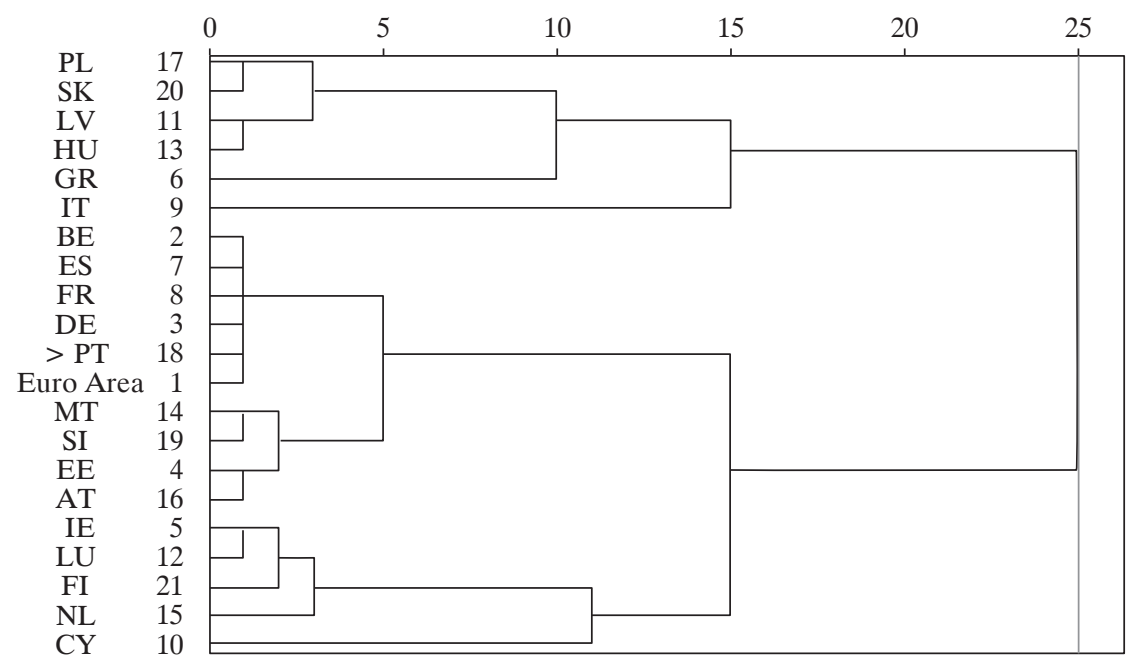

Fig. 8. Clusters by Value of Financial Assets and Debt Held (Clusters Combined, Distances Adjusted)

Source: author's own calculations on the basis of the HFCS, https://www.ecb.europa.eu/pub/ economic-research/research-networks/html/researcher_hfcn.en.html. 
In terms of the percentage of households holding financial products, France and Italy seem to be most similar to the average for the Euro Area, although the biggest cluster of countries consists of Estonia, Slovakia, Hungary, Slovenia, Latvia, Poland, and Greece. Close to the average is a group of three countries: Germany, Austria, and Malta. The other group of clusters is more diversified. It consists of a cluster containing three countries: Spain, Finland, and Portugal, which are joined with Belgium. The second part of this group of clusters consists of two two-member groups, the first comprising Luxembourg and the Netherlands, and the second Ireland and Cyprus, but their heterogeneity is higher.

If we analyse the heterogeneity of countries by the value of financial assets and debt held by households, it should be pointed out that the biggest cluster consists of the Euro Area and five countries: Belgium, Spain, France, Germany, and Portugal. At the same time, there are three countries - Greece, Italy, and Cyprus - which are so different from the others that each of them makes up a separate group. We also have a two-country cluster comprising Poland and Slovakia, which at the higher level can be compared with Latvia and Hungary. The same is true of Malta and Slovenia, which connect with the cluster consisting of Estonia and Austria. Finally, there is a two-country cluster of Ireland and Luxembourg, which is joined by Finland and the Netherlands.

\section{Conclusions}

From the analyses presented above one can draw several conclusions. All of them show that there is distinct heterogeneity between household behaviour on some parts of the financial market. The main differences are in the value and structure of financial assets held by households in particular countries as well as in the value and structure of their debt. The basic distinction is that households from the wealthier countries are more active on financial markets and have more opportunities to invest their money in financial instruments or a broader choice of lending products. However, wealth is not the only factor influencing households behaviour. The heterogeneity in the structure of financial assets and liabilities in the portfolio of households is not strictly correlated with wealth and financial market development. Another area of differences is the relationship between financial assets and debt held by households. The trends presented in the analysis of the percentage of households holding particular products differ considerably from the results of the analysis of the value of assets and debt. 
In both cases some regularities can be observed, but they are not the same for the number of households and for the value of instruments. The other field of variation between countries is the ages and incomes of the most active households. These are different for households holding financial assets compared to those with debts, which can be explained by life cycle theory. Nevertheless, it would be interesting to conduct further analysis by focusing on households which hold both types of instruments simultaneously.

The final part of the article presents clusters that show in which countries households behave in a similar way. This, in turn, raises many questions about the sources of similarities and differences, which should be a subject for further research.

\section{Bibliography}

Arrondel, L., Bartiloro, L., Fessler, P., Lindner, P., Mathä, T. Y., Rampazzi, C., Savignac, F., Schmidt, T., Schürz, M. and Vermeulen, P. (2016) "How Do Households Allocate Their Assets? Stylized Facts from the Eurosystem Household Finance and Consumption Survey". International Journal of Central Banking 2 (12).

Arrondel, L., Roger, M. and Savignac, F. (2014) Wealth and Income in the Euro Area: Heterogeneity in Households' Behaviours. Direction Générale des Études et des Relations Internationales.

Arrondel, L. and Savignac, F. (2016) "Households' Real Estate and Financial Asset Holdings: What Differences in Investment Behaviour within the Euro Area?". Rue de la Banque 19: 1-2.

Bover, O., Schürz, M., Slacalek, J. and Teppa, F. (2016) "Eurosystem Household Finance and Consumption Survey: Main Results on Assets, Debt, and Saving”. International Journal of Central Banking 12 (2): 1-13.

Christelis, D., Ehrmann, M. and Georgarakos, D. (2015) "Exploring Differences in Household Debt Across Euro Area Countries and the United States". Working Papers, Bank of Canada (2015-16).

Du Caju, P., Roelandt, T., Van Nieuwenhuyze, C. and Zachary, M. D. (2014) "Household Debt: Evolution and Distribution”. Economic Review, September, 61-80.

Georgarakos, D., Haliassos, M. and Pasini, G. (2014) "Household Debt and Social Interactions". Review of Financial Studies 27 (5): 1404-1433, https://oi.org/10.1093/ rfs/hhu014.

Kukk, M. (2014). Distinguishing the Components of Household Financial Wealth: the Impact of Liabilities on Assets in Euro Area Countries. Eesti Pank. Working Paper Series No. 2. 


\section{Abstract \\ Zróżnicowanie gospodarstw domowych w strefie euro, na Węgrzech oraz w Polsce w zakresie wykorzystania aktywów finansowych i zadłużenia na podstawie Household Finance and Consumption Survey}

W artykule przedstawiono analizy koncentrujące się na obszarach, w których występują różnice w zachowaniach gospodarstw domowych w wybranych krajach pod względem posiadania aktywów finansowych i długu. Autorka stawia hipotezę, że chociaż kraje strefy euro mają wspólną politykę monetarną, która określa niektóre warunki rynku finansowego i działalność instytucji finansowych, zachowanie gospodarstw domowych na rynkach finansowych znacznie się różni. Przedmiotem analiz była struktura instrumentów finansowych posiadanych przez gospodarstwa domowe oraz aktywność gospodarstw domowych na wybranych rynkach finansowych z uwzględnieniem ich wieku i dochodów. Autorka przeprowadziła także analizę heterogeniczności gospodarstw domowych za pomocą hierarchicznej analizy skupień, która wykazała znaczną różnorodność odsetka gospodarstw domowych posiadających aktywa finansowe wraz z długiem oraz różnorodność wartości posiadanych przez nie produktów finansowych.

Słowa kluczowe: finanse gospodarstw domowych, aktywa finansowe, zadłużenie gospodarstw domowych, dystrybucja aktywów. 